\title{
DETECTION ON CAMPYLOBACTER FETUS IN SHEEPING NORTH AREA OF SYRIA
}

\author{
M.ELEWE ${ }^{*}$ and Y.AL-YASENO** \\ *Dept. of infectious Diseases, Fac.Vet. Med. AL-Baath University. \\ ** Dept. of infectious Diseases, Fac.Vet. Med. AL-Baath University. \\ Email: mhmadelewe@hotmail.com
}

\section{ABSTRACT}

Received at: $30 / 6 / 2014$

This study has been carried out on 202 aborted ewes in 15 sheep flocks in 4 Syrian provinces (Aleppo - Alraqa- Alhasaka- Der alzor). Then the bacterial and

Accepted: 10/9/2014 biochemical tests have been carried out 202 samples. The samples were taken from the aborted ewes and its fetuses. The samples of aborted ewes are (gall-bladder, placenta, vaginal swabs) and the samples of fetuses are (liver, spleen, kidney, stomach contents). It has been proved that 15 isolates have shown positive results for campylobacter fetus which equals $7.4 \%$. The highest percentage of abortions caused by campylobacter in Aleppo was $10.5 \%$, whereas it was $6.9 \%$ in Alraqa, the percentage was $5.4 \%$ in Der alzor. No positive results have been recorded in Alhasaka. Most of positive isolates from ewes managed in concentrated system.

Key words: Campylobacter, abortion, fetus.

\section{الكثف عن المقوسة الجنينية في المنطقة الثمالية من سورية \\ محمد العلبيوي ، ياسين الياسينو \\ Email:}

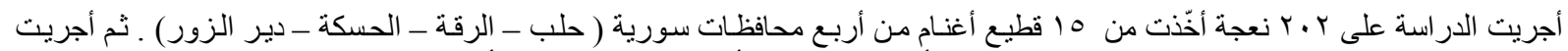

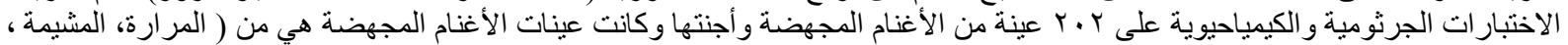

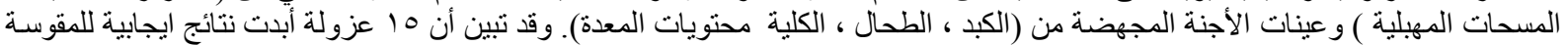

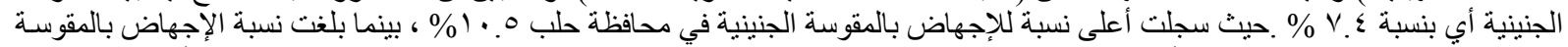

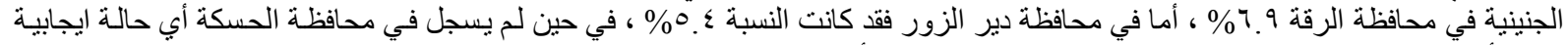

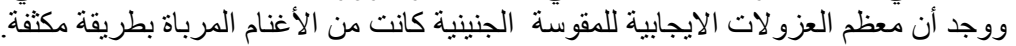

\section{INTRODUCTION}

\section{المقدمة}

أول من كتب عن المقوسة الجنينية تحت نوع الجنينية كان العالم Escherich ، حيث كتب مقالة علمية تضمنت وصف لجر اثيم لولبية أخذت من

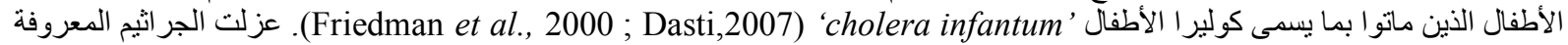

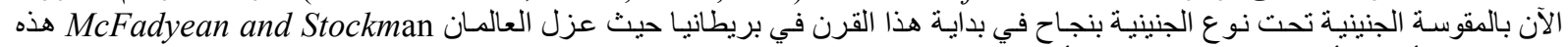

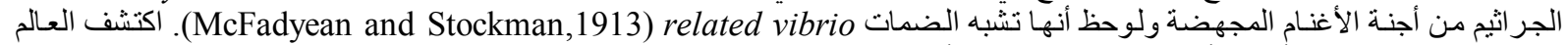
Smith

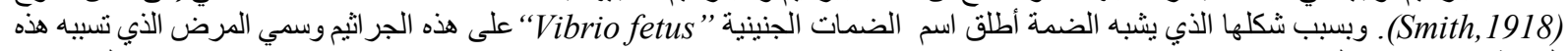

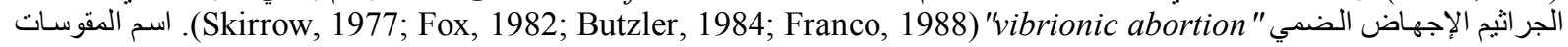

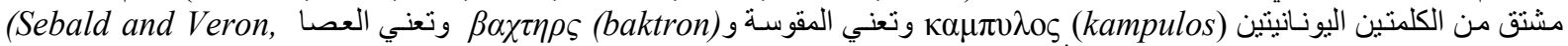

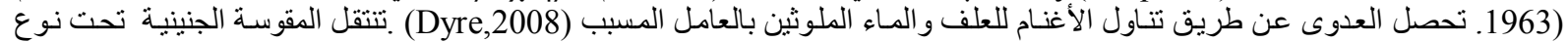

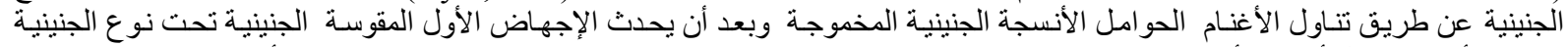

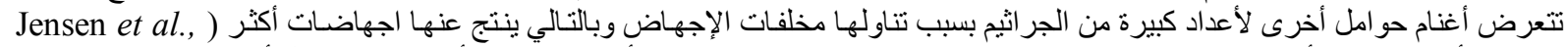

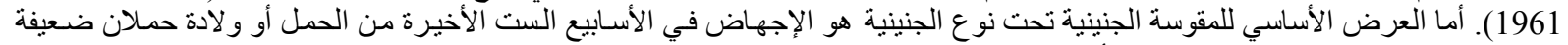

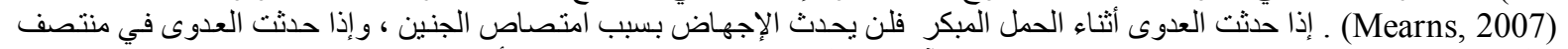

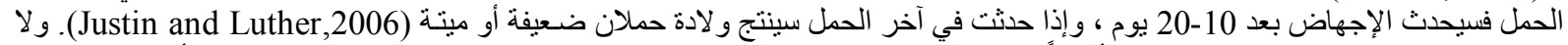

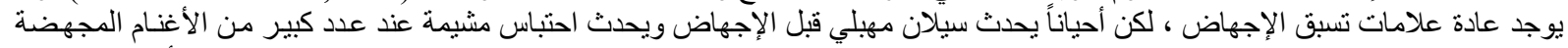

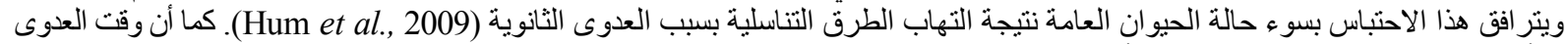

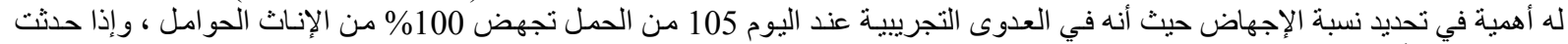

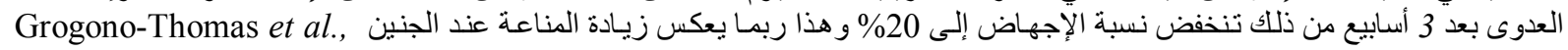


(2000). يمكن عزل المقوسة الجنينية تحت نوع الجنينية من المشيمة و الدم ومحتويات الأمعاء والمرارة والإفر ازات المهيلية من الأغنام الهخموجة ومن محتويات المعدة و القلب و الدم و الكبد و الرئة من الجنين المجهض فئنة يهدف البحث إلى الكثف عن المقوسة الجنينية في المنطقة الثمالية من سورية.

\section{MATERIALS and METHODS \\ مواد وطرائق البحث}

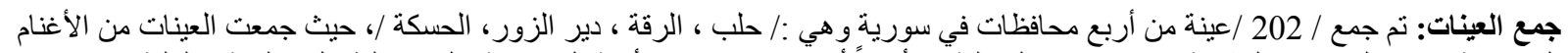

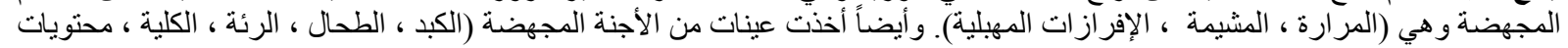

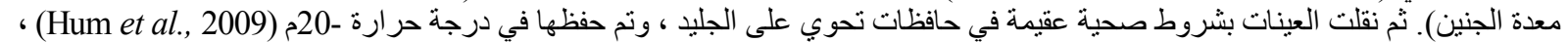

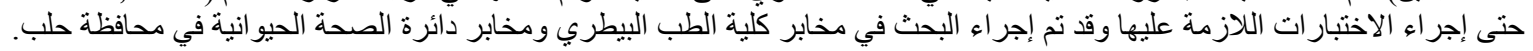

$$
\begin{aligned}
& \text { الأجهزة المستخذمة : } \\
& \text { Autoclave الصاد الموصدة: . } \\
& \text { Incubator الحاضنة - } \\
& \text { " مefrigerator ثلاجة } \\
& \text { " Macroscope مجرة " }
\end{aligned}
$$

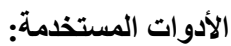
Anaerobic Jar • •

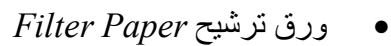

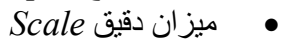

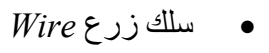

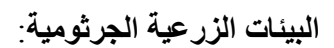

أ- وسط سكيرو أغار الخاص بالكامبيلوباكتر: Skirrow's Campylobacter selective medium

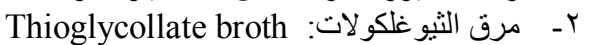

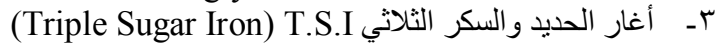

المحاليل المستخدمة لإجراء الاختبارات الكيمياحيوية : المبات

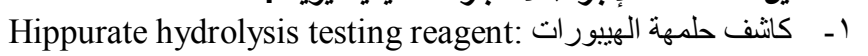

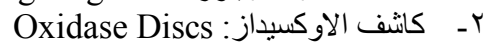

r

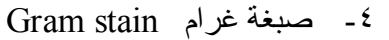

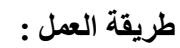

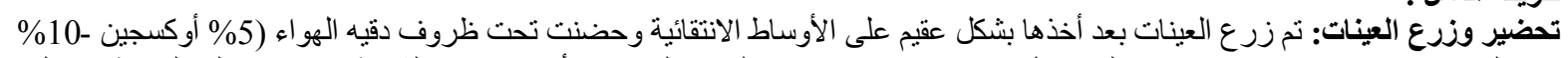

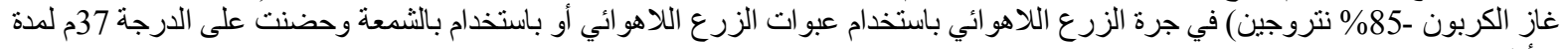

التعرف على المقوسة الجنينية

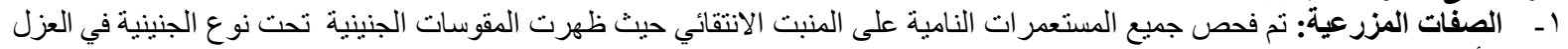

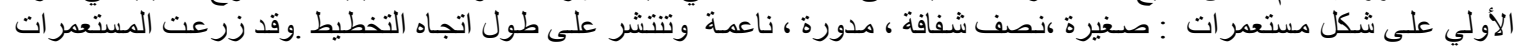

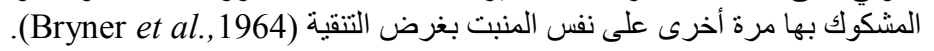

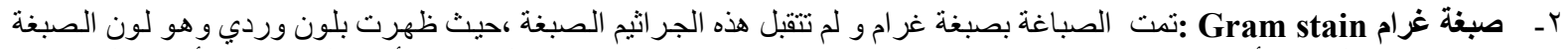

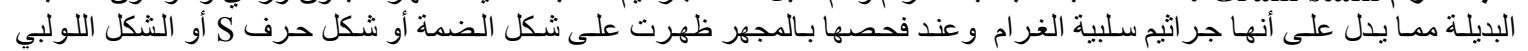

(Smibert, 1974)

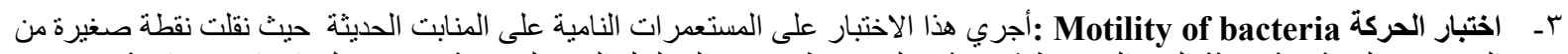

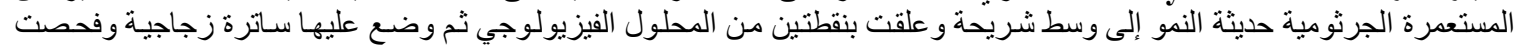

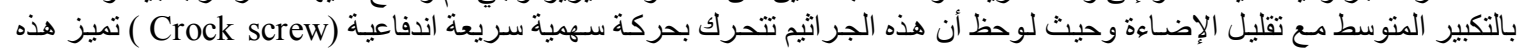

الجر اثيم (Kudirkiene et al., 2008).

ع - الاختبارات الكيمياحيوية Biochemical Tests: تهدف الاختبار ات الكيمياحيوية للتمييز بين المقوسة الجنينية تحت نوع الجنينية والمقوسة الصائمية لأنهما أهم المقوسات المسبية للإجهاض عند الأغنام. 


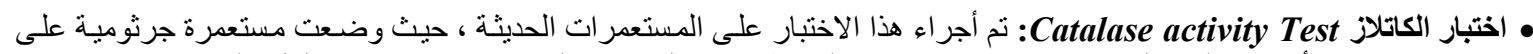

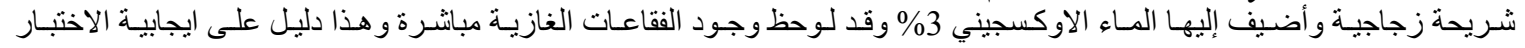

.(Kudirkiene et al., 2008)

• اختبار الاوكسيداز Oxidase Test : أخذنا قرص من أقر اص الكاشف الجاهزة فرشنا المستعمرة الجرثومية بواسطة سلك الزرع على القرص فلاحظنا تغير اللون إلى بنفسي خلاز 10 دقائق (Kudirkiene et al., 2008).

• اختبار إنتاج كبريت الهيروجين Hydrogen sulphide production H

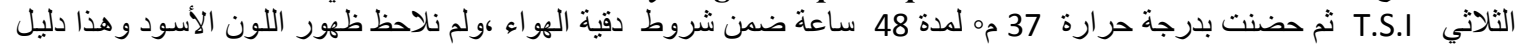

على سلبية الاختبار (Park et al.,1984).

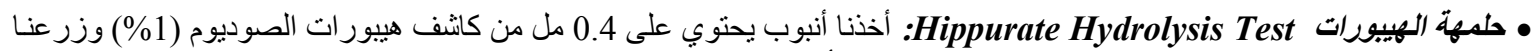

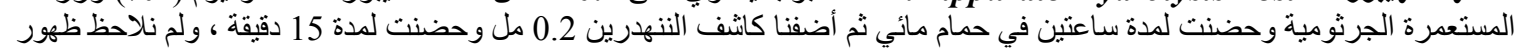

اللون البنفسي دليل على سلبية الاختبار (Baron et al.,1994).

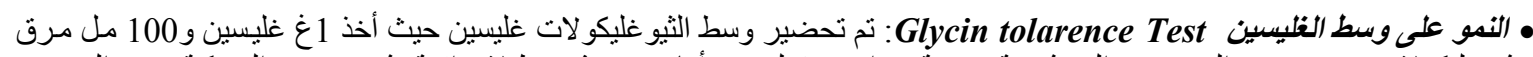

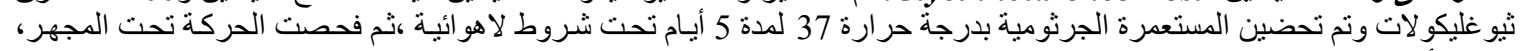

فلوحظ أن هذه الجر اثيم تتحرك بحركتها النهينة الجرية المميزة (Park et al.,1984).

\section{RESULTS \\ النتائج}

أظهرت الدر اسة وجود 15 عزولة ايجابية (7.4\%) للمقوسة الجنينية تحت نوع الجنينية من 202عينة نم در استها. وكانت نسبة العزولات الإيجابية

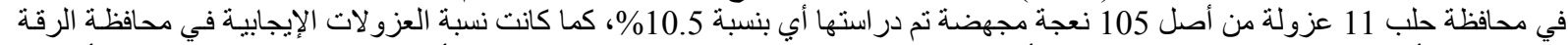

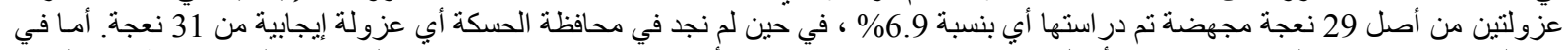

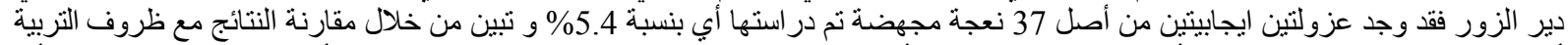

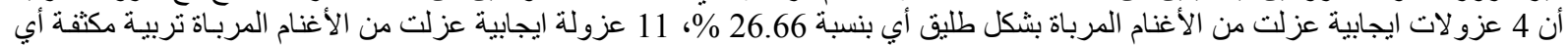
بنسبة 73.33\%

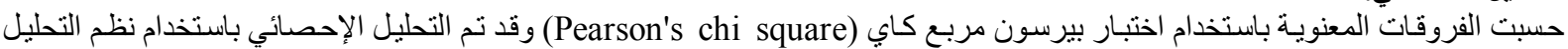

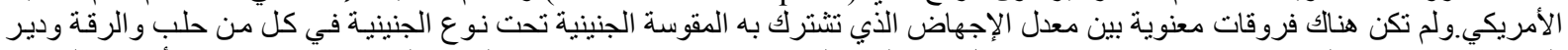

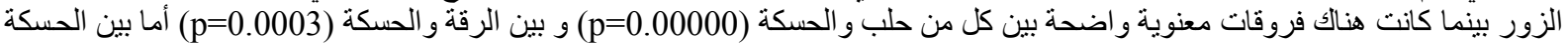

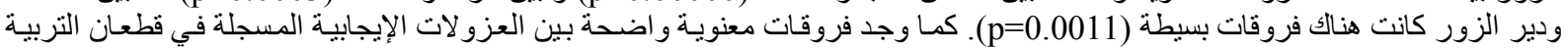

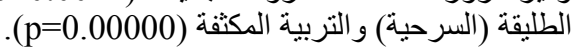

\section{DISCUSSION}

المناقثة

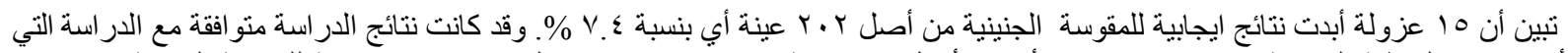

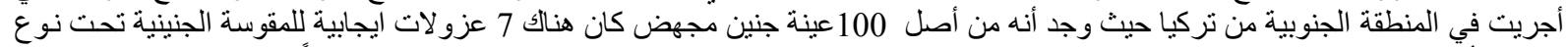

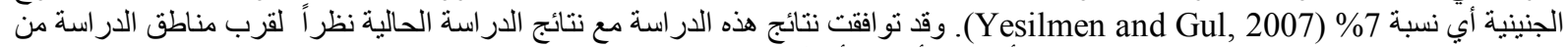

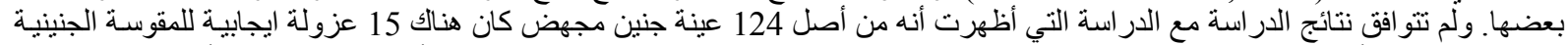

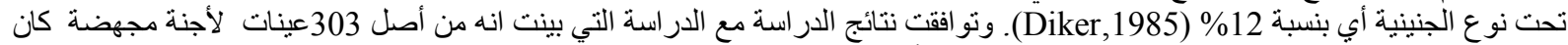

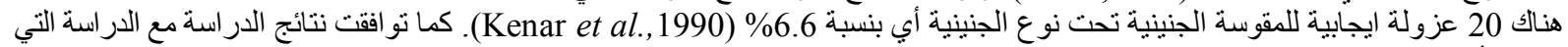

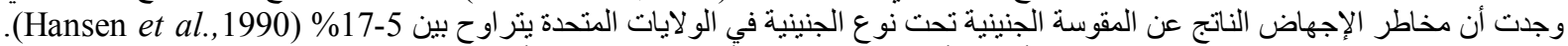

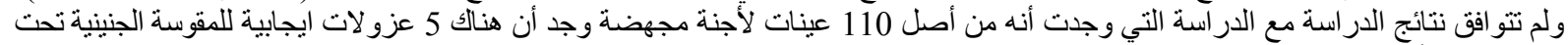

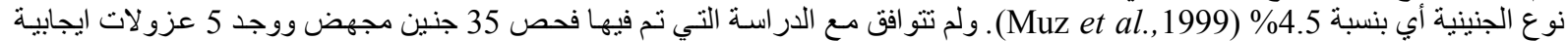

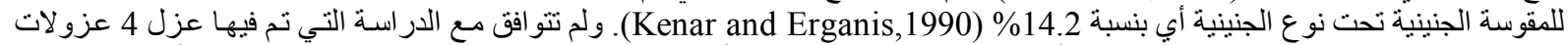

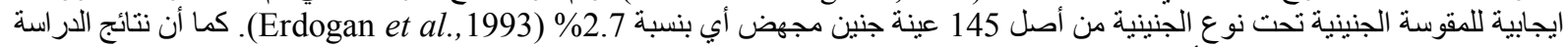

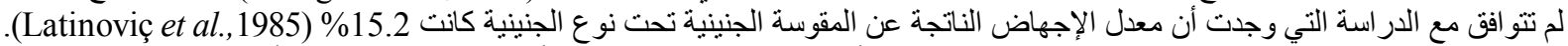

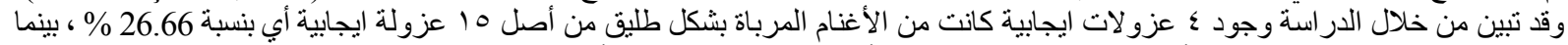

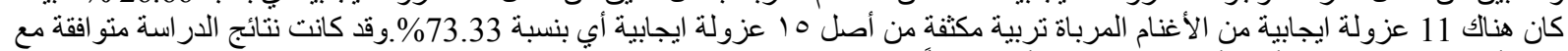

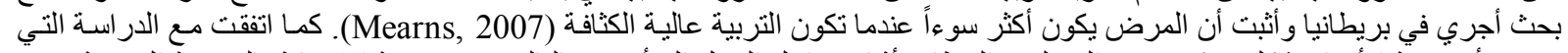

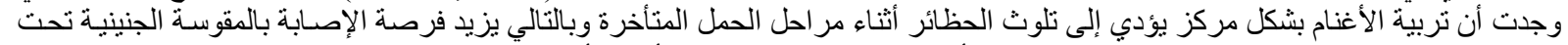

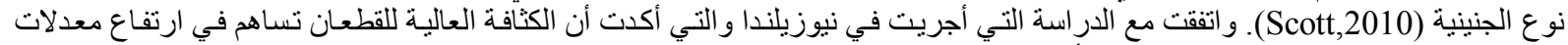
إجهاض بالمقوسة الجنينية تحت نوع الجنينية أكثر من القطعان ذات الكثافة المنخفضة (Quinlivan and Jopp, 1982). 


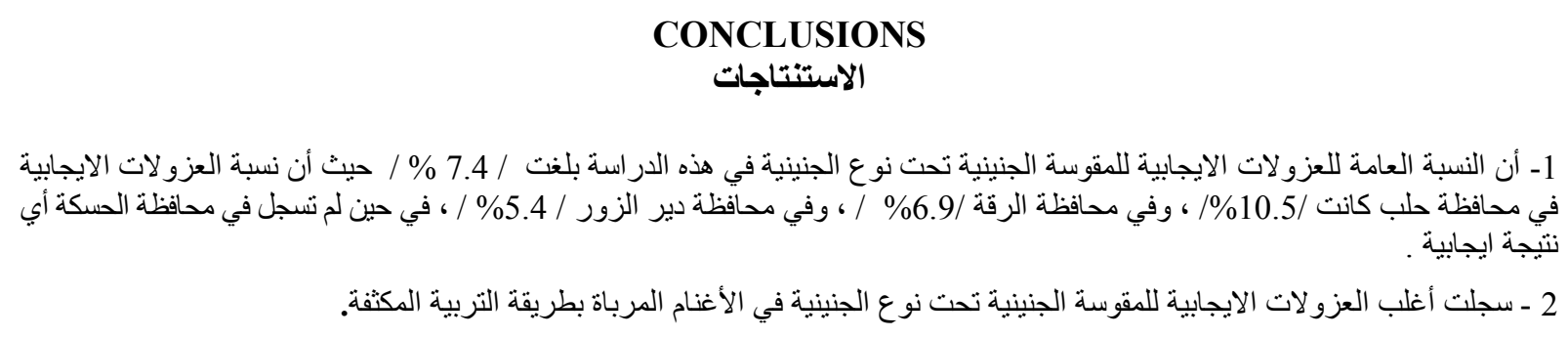

\section{REFERENCES المراجع}

Baron, E.J.; Peterson, L.R. and Finegold, B.M. (1994): Baily and scott's Diagnostic Microbiology.9th Ed. Mosby, St. Louis Baltimore.

Bryner, J.H.; O'Berry, P.A. and Frank, A.H. (1964): Vibrio infection of the digestive organs of cattle .Am. J. Vet. Res., 25: 1048-1050.

Butzler, J. (1984): Campylobacter Infection in Man and Animals. CRC Press, Inc. Boca Raton, FL.

Dasti, J.I. (2007): Identification and characterization of campylobacter jejuni factors relevant for the infection process ph.D. Thesis, George August University, Germany.

Diker, K.S. (1985): Studies on the identification of Campylobacter species isolated from sheep and cattle. Doga Bilim. Derg. 9, 232-240.

Dyre, N.W. (2008): Diagnosis of Ovine Abortion - Getting the Most Out of Your Diagnostic Laboratory. Sheep Research Report: 13-14.

Erdogan, I.; Gurel, A.; Tekin, C.; Uyanýk, F. and Bitgel, A. (1993): The determination and distribution of bacterial abortus in goats, cow and sheep in Thrace region. J. Pendik Vet. Microbiol. 24, 23-35.

Fox, J.G. (1982): Campylobacteriosis: a "new" disease in laboratory animals. Lab Anim Sci, 32: 625-637.

Franco, D.A. (1988): Campylobacter species: considerations for controlling a foodborne pathogen. J. Food. Prot. 51: $145-153$.

Friedman, C.R.; Neimann, J.; Wegener, H.G. and Tauxe, R.V. (2000): Epidemiology of Campylobacter jejuni infections in the United States and other industrialized nations. In: Nachamkin I., Blaser M. J. Campylobacter. Washington: ASM Press; p. 121-39.

Grogono-Thomas, R.; Dworkin, J.; Blaser, M.J. and Newell, D.G. (2000): Roles of the surface layer proteins of Campylobacter fetus subsp. fetus in ovine abortion. Infect Immun .68: 1687-1691.

Hansen, D.E.; Hedstrom, O.R.; Sonn, R.J. and Synder, P.S. (1990): Efficacy of a vaccine to prevent Chlamydia or Campylobacter induced abortions in ewes. JAVMA, 196, 731-734.

Hum, S.; Hornitzky, M. and Berg, T. (2009): Ovine Campylobacteriosis. Elizabeth Macarthur Agricultural Institute. Australia: 1-8.

Jensen, R.; Miller, V.A. and Molello, J.A. (1961): Placental pathology of sheep with vibriosis. American journal of veterinary Research22 (87)169-185.

Justin, S. and Luther, Ph.D. (2006): Abortions in Sheep Causes, Control and Prevention. NDSU Extension Sheep Specialis, AS-1317.

Kenar, B. and Erganis, O. (1990): Isolation and antibiotic susceptibility of Campylobacter spp. in aborted ovine fetuses in the central Black Sea. Veterinarium .5, 4-11.

Kenar, B.; Erganis O.; Kaya O. and Guler L. (1990): Bacteriological and serological survey on brucella, campylobacter, salmonella and chlamydia infections caused to sheep abortion in Konya region (central Anatolia) in Turkey. Veterinarium, 1, 17-20 (in Turkish).

Kudirkiene, A.; Malakauskas, A.; Serniene, L. and Malakauskas, M. (2008): Isolation and identifaction of thermophilic Campylobacter ssp. by PCR-RFLP in broiler flocks. Veterinarija IR Zootechnik, A. 42(64): 44-46.

Latinoviç, V.; Popovic, M. and Nevjestic, A. (1985): Privi slucajevi izolacije bakterija roda Campylobacter kod goveda i ovaca u Srbich. Veterinaria, Sarajevo. 34, 367-375.

Mc fadyean, J. and Stockman, S. (1913): Report of the Departmental committee appointed by the board of the Agriculture and Fisheries to inquire into Epizootic Abortion.part3.Abortion in sheep. London: HMSO.

Mearns, R. (2007): Campylobateriosis. pages131-132 In: Diseases of sheep ed, I. D. Aitken. Blackwell publishing, Oxford, U.K.

Muz, A.; Ertas, H.B.; Ongor, H.; Gulcu, H.B.; Ozer, H.; Eroksuz, H.; Dabak, M.; Basbug, O. and Kalender, H. (1999): Bacteriologic, serologic and pathologic studies on aborted cases of goats and sheep in Elazýd and it.s vicinity. Tr. J. Vet. Anim. Sci., 23, 177-188. 
Park, C.E.; Smibert, R.M.; Blaser, M.J.; Vanderzant, C.; Stern, N. (1984): Campylobacter in: "Compendium of methodes for the Microbiological examination of food "2 ${ }^{\text {nd }}$ Ed. Speck. M(ed) American public Health Association, Washington, D.C.

Quinliven, T.D. and Jopp, A.J. (1982): A survey on the incidence and cause of ovine abortion in Hawkes Bay.Newzealand veterinary journal 30(5)65-68.

Scott, ph. (2010): Abortion in ewes. the National Animal Disease Information Service (Nadis). [Internet]. Available at: www. nadis. org. UK.

Sebald, M. and Veron, M. (1963): Teneur en bases de I'ADN et classification des vibrions. Ann. Inst. Pasteur (Paris) 105: 897-910.

Skirrow, M.B. (1977): Campylobacter enteritis: a "new” disease. Br. Med. J. 2: 9-11.Smith, T.; Orcutt, M.L. (1927). Vibrios from calves and their serological relationto Vibirio fetus. J. Exp. Med. 45: 391-397.

Smibert, R.M. (1974): Genus II. Campylobacter Sebald and Veron 1963, 907, p. 207-212. In R. E. Buchanan and N. E. Gibbons (ed.), Bergey's manual of determinative bacteriology, 8th ed. The Williams \& Wilkins Co., Baltimore.

Smith, T. (1918): Spirilla associated with disease of the fetal membranes in cattle (infectious abortion). J. Exp. Med. 28:701-719.

Yesilmen, S. and Gul, K. (2007): Isolation, identification and antibiotic susceptibility of campylobacter ssp. in aborted sheep fetuses medycyna wet.63 (10). 